\title{
Teh daun kelor (moringa oleifera tea) terhadap kadar hemoglobin dan hepcidin ibu hamil
}

\author{
Nurul Hikmah, ${ }^{1 *}$ Werna Nontji, ${ }^{2}$ Veni Hadju, ${ }^{3}$ \\ ${ }^{1}$ Program Studi IImu Kebidanan Pascasarjana Universitas Hasanuddin, Indonesia \\ ${ }^{2}$ Departemen Kebidanan, Universitas Hasanuddin, Indonesia \\ ${ }^{3}$ Departemen Gizi Kesehatan Masyarakat, Universitas Hasanuddin, Indonesia.
}

\begin{abstract}
Moringa leaves are a plant that is rich in Beta Carotene, Protein, Vitamins A, C, Potassium, Calcium, and Iron in high amounts that are easily digested and assimilated by the human body so pregnant women need to increase hemoglobin and hepcidin levels. This research aims to describe of giving of iron tablet and Moringa oleifera tea on hemoglobin and Hepcidin levels in pregnant women. This research is a quantitative study, Quasi Experiment non-randomized control group pretest-posttest design in third trimester pregnant women ( $\geq 28$ weeks) at the Pangkajene public Health Center and Lawawoi public Health Center of Sidenreng Rappang Regency. 36 people were divided into two groups, namely the intervention group of mothers who consumed iron tablet and Moringa oleifera tea $(n=18)$ and the control group who consumed iron tablet $(n=18)$. The implementation was conducted for 60 days and then performed pretest and posttest blood sample. Ptaken was, hemoglobin was measured by hematology analyzer and hepcidin was measured by ELISA method. Statistical analysis was performed by measuring pre and post by paired t-test, and for intergroup difference test with independent samples t-test if the data were not normally distributed using Wilcoxon ranked t-test and intergroup difference test with mann whitney test with a significant level of $p<0.05$. The results of the research indicate that there is an effect of giving iron tablet and Moringa leaf tea on the increaseof hemoglobin level in pregnant women $(p=0.001)(p<0.05)$ in which the mean level of hemoglobin is $11.78 \pm 0.58$. however, there is no effect of iron tablet and Moringa leaf tea on hepcidin level $(p=0.429(p>0.05)$ in which the average level of hepcidin level is $0.560 \pm 1.10$. Thus,the consumption of iron tablet and Moringa leaf tea is better to increase hemoglobin level.
\end{abstract}

Keywords: Iron Tablet, Moringa Leaf Tea, Pregnant Women, Hemoglobin Level, Hepcidin Level

Daun kelor merupakan tanaman yang kaya akan Beta Karoten, Protein, vitamin A, C, Kalium, Kalsium, dan Zat Besi dalam jumlah tinggi yang mudah dicerna dan diasimilasi tubuh manusia khususnya sangat diperlukan ibu hamil untuk meningkatkan kadar hemoglobin dan hepcidin. Penelitian ini bertujuan untuk menggambarkan pemberian tablet zat besi dan teh daun kelorterhadap kadar hemoglobin dan Kadar Hepcidin ibu hamil. Penelitian ini merupakan penelitian kuantitatif,Quasi Experiment non randomized control group pretest-posttest design pada ibu hamil trimester III ( $\geq 28$ minggu)di Puskesmas Pangkajene

"Corresponding Author: nurulhikmah@pasca.unhas.ac.id 
dan Puskesmas Lawawoi Kabupaten Sidenreng Rappang. sebanyak 36 orang dibagi menjadi dua kelompok yaitu kelompok intervensi ibu yang mengonsumsi tablet zat besi dan teh daun kelor $(n=18)$ dan kelompok kontrol yang mengonsumsi tablet zat besi $(n=18)$. Implementasi dilakukan selama 60 hari kemudian dilakukan pretest dan posttest pengambilan darah,hemoglobin diukur dengan hematologi analyzer dan hepcidin diukur dengan metode ELISA.Analisis statistik dilakukan dengan mengukur pre dan post dengan paired t-test, dan untuk uji beda antar kelompok dengan independent samples t-test bila data tidak terdistribusi normal menggunakan Wilcoxon ranked t-test dan uji beda antar kelompok dengan uji mann whitney dengan tingkat signifikan $\mathrm{p}<0.05$. Hasil penelitian ini menunjukkan bahwa ada pengaruh pemberian tablet zat besi dan teh daun kelor pada peningkatan kadar hemoglobin ibu hamil dimana $(p=0,001)(p<0,05)$ rerata kadar hemoglobin: $11.78 \pm 0.58$. Namun tidak ada pengaruh pemberian tablet zat besi dan teh daun kelor pada kadar hepcidin $(p=0.429(p>0.05)$ dimana rerata kadar hepcidin: 0.560 \pm 1.10 , sehingga konsumsi tablet zat besi dan teh daun kelor lebih baik pada peningkatan kadar Hemoglobin.

Kata Kunci: Teh Daun Kelor, Ibu hamil, Kadar Hemoglobin, Kadar Hepcidin

\section{Pendahuluan}

Penyebab lain terjadinya anemia pada status gizi selain disebabkan oleh kadar hemoglobin ibu tidak normal yaitu < $11 \mathrm{gr} / \mathrm{dl}$ juga di karenakan peningkatan kadar hepsidin. Hepsidin berperan sebagai regulator zat besi dalam tubuh manusia. Sintesis hepsidin akan menyebabkan penekanan terhadap penyerapan besi oleh usus halus, penurunan kadar besi dalam sirkulasi, serta menekan pengeluaran besi dari tempat penyimpanannya sehingga dapat berperan dalam penurunan kadar hemoglobin (Ratulangi \& Kaligis, 2017)(Young et al., 2019)

World Health Organization (WHO) melaporkan bahwa prevalensi ibu hamil yang mengalami defisiensi besi sekitar 35-75\% semakin meningkat seiring dengan pertambahan usia kehamilan dan diperkirakan 30-40\% penyebab anemia karena kekurangan zat besi (WHO, 2019). Di Indonesia, menunjukkan hampir separuh atau sebanyak 48,9\% ibu hamil mengalami anemia. Sedangkan data dari Dinas Kesehatan Kabupaten Sidenreng Rappang tahun 2017 ibu hamil anemia sebanyak 1643 orang (27,2\%), dan tahun 2018 ibu hamil yang menderita anemia sebanyak 1127 orang $(18,7 \%)$. (Dinkes, 2019). Angka ini belum mencapai angka nasional yang telah ditetapkan oleh kementrian kesehatan di tahun 2018 (Kemetrian Kesehatan Republik Indonesia, 2018)

Sesuai dengan Permenkes No. 97 tahun 2014 pasal 12 Salah satu upaya pemerintah untuk mengatasi anemia defisiensi besi pada ibu hamil adalah dengan pemberian tablet tambah darah (Fe) (Kemenkes Rl, 2014). (Kesehatan et al., 2014)Secara nasional cakupan ibu hamil mendapat tablet Fe adalah $85 \%$ dan rata-rata pemberian tablet Fe di Sulawesi selatan dibawah rata-rata nasional (Kemenkes, 2016). Kurang berhasilnya pemberian tablet besi selain 
disebabkan oleh masalah yang berkaitan dengan manajemen program, kepatuhan, jadwal pemberian, perlu juga dipertimbangkan zat gizi yang dikonsumsi, selain itu juga efek dari tablet besi $(\mathrm{Fe})$ yaitu mual dianggap sebagai salah satu faktor ketidakpatuhan ibu dalam mengkonsumsi tablet besi (Fe) tersebut (Depkes, 2018).

Berdasarkan efek samping pemberian tablet besi $(\mathrm{Fe})$ yang terjadi pada ibu hamil, selain $\mathrm{Fe}$ juga dapat diberikan ekstrak daun kelor dalam bentuk teh daun kelor. Saat ini pemberian teh daun kelor dan tablet besi ( $\mathrm{Fe}$ ) dianggap mampu memberikan pengaruh terhadap kadar hemoglobin $(\mathrm{Hb})$ ibu hamil. Hal ini berdasarkan penelitian yang telah dilakukan(Nadimin et al., 2015) bahwa kelompok yang diberi tablet Fe saja tidak cukup meningkatkan kadar hemoglobin, sebaliknya pada kelompok yang diberikan tambahan ekstrak daun kelor terdapat peningkatan signifikan kadar hemoglobin ibu hamil.

Berdasarkan uraian diatas agar terpenuhinya kebutuhan zat besi pada ibu hamil maka salah satu intervensi yang akan dilakukan penulis adalah pemberian teh daun kelor. Teh daun kelor mengandung zat besi yang diperlukan ibu hamil untuk meningkatkan sel darah merah atau meningkatkan hemoglobin (Winarno, 2018)
Penelitian dan publikasi tentang pemanfaatan daun kelor khususnya dalam bentuk teh daun kelor pada ibu hamil anemia masih jarang ditemukan. Oleh Karena itu peneliti bermaksud melakukan penelitian dengan tujuan untuk menggambarkan pemberian tablet zat besi dan teh daun kelor terhadap kadar hemoglobin dan Kadar Hepcidin ibu hamil.

\section{Metode}

\section{Desain penelitian dan sampel}

Penelitian ini merupakan penelitian kuantitatif,Quasi Experiment non randomized control group pretest-posttest design.Penelitian dilaksanakan di Puskesmas Pangkajene dan Puskesmas Lawawoi Kabupaten Sidenreng Rappang mulai tanggal 6 September-12 November 2019. Populasi dalam penelitian ini adalah semua ibu dengan usia kehamilan trimester III atau $\geq 28$ minggu yang melakukan kunjungan ANC sebanyak 103 ibu hamil yaitu di Puskesmas Pangkajene sebanyak 56 ibu hamil dan Puskesmas Lawawoi sebanyak 47 ibu hamil di Kabupaten Sidenreng Rappang. Teknik sampel yang digunakan dalam penelitian ini adalah Non probability sampleyaitu purposive samplingpada dua kelompok, kelompok intervensi yang diberi teh daun kelor dan tablet zat besi $(n=18)$ serta kelompok kontrol yang hanya diberi tablet zat 
besi ( $n=18$ ) dengan kriteria Inklusi, Eksklusi, dan Drop out.

\section{Pengumpulan Data}

Pengumpulan data dilakukan setelah responden diberi penjelasan oleh peneliti dan bersedia menjadi responden dalam penelitian, responden menandatangani informed consent sebagai bukti persetujuan responden. Skrining awal menggunakan lembar checklist dengan mewawancarai terkait data karakteristik responden berupa pernyataan mengenai inisian responden, umur, jarak kehamilan, paritas, pendidikan, alamat, no. telpon dan melakukan anamnesa lengkap kepada responden.. Jika responden bersedia menjadi subyek penelitian ini maka peneliti akan memberikan teh daun kelor yang dikonsumsi 2 kali sehari yaitu pada pagi dan sore hari masing-masing 1 kantung teh (1 kantung berisi 2,5 gram). Sebelum diberikan teh daun kelor akan dilakukan pengambilan sampel darah di RSUD Nene Mallomo Kab. Sidenreng Rappang oleh analis kesehatan. Sampel darah sebanyak $5 \mathrm{~mL}$ di vena antecubital, lalu dimasukkan ke dalam tabung vacutainer dan memberikan kode responden pada tabung untuk pemeriksaan jumlah hemoglobin dengan menggunakan Hematologi analyzer yang dilakukan oleh petugas analis kesehatan. Sisa sampel darah kemudian dibawa ke Laboratorium penelitian RS PTN UNHAS menggunakan cool box. Selanjutnya sampel darah akan disentrifugasi selama 10-20 menit pada 20003000 RPM dan disimpan dalam lemari pendingin dengan temperatur $\pm-200 C$. Setelah seluruh sampel diperoleh maka seluruh sampel darah akan diperiksa kadar serum hepcidinnya di Laboratorium penelitian RS PTN UNHAS Makassar dengan menggunakan Human Hepcidin ELISA kit. Setelah dilakukan intervensi selama 8 minggu dengan memberikan teh daun kelor, kembali dilakukan pemeriksaan kadarhemoglobin dan hepcidin ibu.

\section{Analisis Statistik}

Analisis univariat menampilkan Distribusi Frekuensi Responden Berdasarkan Karakteristik responden, Pola Makan, Kadar Hemoglobin dan Kadar Hepcidin Ibu Hamil Pada Kelompok Intervensi dan Kelompok Kontrol. Pada analisis bivariate untuk mengetahui perbedaan sebelum dan sesudah perlakuan. Hasil analisisnya ditampilkan dalam bentuk narasi dan 2 uji, yaitu uji beda dan frekuwensi. Dilakukan dengan mengukur pre dan post dengan paired t-test, dan untuk uji beda antar kelompok dengan independent samples t-test bila data tidak terdistribusi normal menggunakan Wilcoxon 
ranked t-test dan uji beda antar kelompok signifikan $p<0.05$.

dengan uji mann whitney dengan tingkat Hasil dan Pembahasan

Tabel 1. Distribusi Frekuensi Responden Berdasarkan Karakteristik pada Kelompok Intervensi dan Kontrol

\begin{tabular}{|c|c|c|c|c|c|}
\hline \multirow[t]{2}{*}{ Karakteristik Responden } & \multicolumn{2}{|c|}{$\begin{array}{c}\text { Intervensi } \\
(n=18)\end{array}$} & \multicolumn{2}{|c|}{$\begin{array}{c}\text { Kontrol } \\
(n=18)\end{array}$} & \multirow[t]{2}{*}{$p$} \\
\hline & $\mathrm{n}$ & $\%$ & $\mathrm{n}$ & $\%$ & \\
\hline \multicolumn{6}{|l|}{ Umur } \\
\hline$<20$ tahun & 0 & 0 & 2 & 11.1 & $0.126^{*}$ \\
\hline 21-25 tahun & 6 & 33.3 & 9 & 50.0 & \\
\hline 26-30 tahun & 9 & 50.0 & 6 & 33.3 & \\
\hline 31-35 tahun & 0 & 0 & 1 & 5.6 & \\
\hline$>36$ tahun & 3 & 16.7 & 0 & 0 & \\
\hline \multicolumn{6}{|l|}{ Pendidikan } \\
\hline SD & 3 & 16.7 & 1 & 5.6 & $0.281^{*}$ \\
\hline SMP & 2 & 11.1 & 2 & 11.1 & \\
\hline SMA & 9 & 50.0 & 13 & 72.2 & \\
\hline Diploma & 1 & 5.6 & 2 & 11.1 & \\
\hline Sarjana & 3 & 16.7 & 0 & 0 & \\
\hline \multicolumn{6}{|l|}{ Pekerjaan } \\
\hline IRT & 13 & 72.2 & 14 & 77.8 & $0.666^{*}$ \\
\hline Guru & 1 & 5.6 & 0 & 0 & \\
\hline Pegawai & 3 & 16.7 & 2 & 11.1 & \\
\hline Pedagang & 1 & 5.6 & 2 & 11.1 & \\
\hline \multicolumn{6}{|l|}{ Jarak Kehamilan } \\
\hline$<1$ tahun & 6 & 33.3 & 8 & 44.4 & $0.776^{*}$ \\
\hline 1-2 tahun & 2 & 11.1 & 2 & 11.1 & \\
\hline$>2$ tahun & 10 & 55.6 & 8 & 44.4 & \\
\hline \multicolumn{6}{|l|}{ Paritas } \\
\hline Primipara & 5 & 27.8 & 8 & 61.5 & $0.298^{*}$ \\
\hline Multipara & 13 & 72.2 & 10 & 55.6 & \\
\hline
\end{tabular}

Berdasarkan Tabel 1 Dari hasil analisis statistik pada semua karakteristik responden menunjukkan tidak terdapat perbedaan yang bermakna antara umur, pendidikan, pekerjaan, jarak kehamilan, dan paritas ibu hamil pada kelompok intervensi dan kelompok kontrol yaitu ( $p>0.05$ ) yang berarti semua karakteristik yang dijadikan sampel tidak berbeda secara signifikan. Dengan kata lain, hasil dari penelitian bukan pengaruh dari karakteristik sampel penelitian. 
Tabel 2. Distribusi Frekuensi Responden Berdasarkan Kadar Hemoglobin dan Kadar Hepcidin Ibu Hamil Pretest dan PosttestPada Kelompok Intervensi dan Kelompok Kontrol

\begin{tabular}{|c|c|c|c|c|}
\hline \multirow[t]{2}{*}{ Variabel } & \multicolumn{2}{|c|}{ Intervensi } & \multicolumn{2}{|c|}{ Kontrol } \\
\hline & $\mathrm{n}$ & $\%$ & $\mathrm{n}$ & $\%$ \\
\hline \multicolumn{5}{|l|}{ Kadar Hemoglobin Pretest } \\
\hline Normal & 0 & 0 & 0 & 0 \\
\hline Tidak Normal & 18 & 100 & 18 & 100 \\
\hline Total & 18 & 100 & 18 & 100 \\
\hline \multicolumn{5}{|l|}{ Kadar Hemoglobin Posttest } \\
\hline Normal & 16 & 88.9 & 11 & 61.1 \\
\hline Tidak Normal & 2 & 11.1 & 7 & 38.9 \\
\hline Total & 18 & 100 & 18 & 100 \\
\hline \multicolumn{5}{|l|}{ Kadar Hepcidin Pretest } \\
\hline Normal & 0 & 0 & 0 & 0 \\
\hline Tidak Normal & 18 & 100 & 18 & 100 \\
\hline Total & 18 & 100 & 18 & 100 \\
\hline \multicolumn{5}{|l|}{ Kadar Hepcidin Posttest } \\
\hline Normal & 0 & 0 & 0 & 0 \\
\hline Tidak Normal & 18 & 100 & 18 & 100 \\
\hline Total & 18 & 100 & 18 & 100 \\
\hline
\end{tabular}

Data primer, 2019

Berdasarkan Tabel 2 menunjukkan pada kelompok intervensi dan kelompok kontrol saat pretest responden dengan kadar hemoglobin normal sebanyak 0 (0\%) dan kadar hemoglobin tidak normal sebanyak 18 orang (100\%) pada masing-masing kelompok. Saat Posttest pada kelompok intervensi responden dengan kadar hemoglobin normal sebanyak 16 (88.9\%) dan kadar hemoglobin tidak normal sebanyak 2 (11.1\%) dan kelompok kontrol responden dengan kadar hemoglobin normal sebanyak 11 (61.1\%) dan kadar hemoglobin tidak normal sebanyak 7 (38.9\%).

Berdasarkan distribusi responden berdasarkan kadar hepcidin dapat diinterprestasikan bahwa pada kelompok intervensi dan kelompok kontrol saat pretest dan posttest responden dengan kadar hepcidin normal sebanyak $0(0 \%)$ dan kadar hepcidin tidak normal sebanyak 18 orang (100\%) pada masing-masing kelompok. 
Teh daun kelor (moringa oleifera tea) terhadap kadar hemoglobin dan hepcidin ibu hamil

Tabel 3. Perbedaan Kadar Hemoglobindan Kadar Hepcidin Ibu Hamil Sebelum dan Setelah pemberian Tablet Zat Besi (Fe) dan Teh Daun Kelor pada Kelompok Intervensi Dan Tablet Zat Besi (Fe) pada Kelompok Kontrol

\begin{tabular}{|c|c|c|c|c|c|}
\hline Kelompok & $\begin{array}{c}\text { Pretest } \\
\text { Mean } \pm \text { SD }\end{array}$ & $\begin{array}{c}\text { Posttest } \\
\text { Mean } \pm \text { SD }\end{array}$ & $\begin{array}{c}P \\
\text { value }\end{array}$ & $\begin{array}{c}\Delta \\
\text { Mean }\end{array}$ & $\begin{array}{c}P \\
\text { value }\end{array}$ \\
\hline \multicolumn{6}{|l|}{ Hemoglobin } \\
\hline Intervensi & $10.53 \pm 0.29$ & $11.78 \pm 0.58$ & $0.001^{\mathrm{a}}$ & 1.25 & \multirow{2}{*}{$0.001^{c}$} \\
\hline Kontrol & $10.43 \pm 0.36$ & $10.95 \pm 0.67$ & $0.002^{\mathrm{a}}$ & 0.52 & \\
\hline \multicolumn{6}{|l|}{ Hepcidin } \\
\hline Intervensi & $0.726 . \pm 1.172$ & $0.560 \pm 1.108$ & $0.001^{b}$ & 0.166 & \multirow[t]{2}{*}{$0.429^{d}$} \\
\hline Kontrol & $0.153 \pm 0.048$ & $0.134 \pm 0.041$ & $0.004^{b}$ & 0.019 & \\
\hline
\end{tabular}

Berdasarkan Tabel 3 menunjukkan nilai rerata kadar hemoglobin pada kelompok intervensi setelah diberi tablet zat besi + teh daun kelor $11.78 \pm 0.58$ dan nilai rerata $10.95 \pm 0.67$ pada kelompok kontrol setelah diberi tablet zat besi ( $\mathrm{Fe}$ ) dengan selisih kenaikan kadar hemoglobin 0.83 , sehingga pemberian tablet zat besi $(\mathrm{Fe})+$ teh daun kelor berefek lebih besar terhadap peningkatan kadar hemoglobin ibu hamil dibandingkan dengan pemberian tablet zat besi (Fe).

Hasil uji statistik dengan menggunakan uji independent samples test didapatkan nilai $p=0.001 \quad(p<0.05)$. Hal ini menunjukkan nilai yang signifikan pada kadar hemoglobin antara kelompok intervensi dan kelompok kontrol. Sehingga dapat disimpulkan bahwa ada perbedaan bermakna antara kadar hemoglobin yang diberi tablet zat besi +teh daun kelordan tablet zat besi saja.
Peningkatan hemoglobin pada ekstrak daun kelor sejalan dengan penelitian di Burkina yang mengatakan adanya hubungan antara kadar hemoglobin dalam darah dengan konsumsi ekstrak daun kelor secara teratur pada ibu hamil yang menderita anemia atau kekurangan kadar hemoglobin dalam darahnya (Zongo, et al, 2013).

Berdasarkan nilai rerata kadar hepcidin pada kelompok intervensi setelah diberi teh daun kelor dan tablet zat besi $0.560 \pm 1.108$ sedangkan nilai rerata pada kelompok kontrol setelah diberi tablet zat besi (Fe) $0.134 \pm 0.041$ dengan selisih 0.426 . Hal ini menunjukkan bahwa pemberian teh daun kelor dan tablet zat besi (Fe) berefek lebih besar terhadap penurunan kadar hepcidin ibu hamil dibandingkan dengan pemberian tablet zat besi (Fe) saja. 
Hasil uji statistik dengan menggunakan uji Menn Wthiney didapatkan nilai $\mathrm{p}=0.429$ $(\rho>0,05)$ yang menunjukkan tidak ada perbedaan bermakna antara kadar hepcidin ibu hamil yang diberi teh daun kelor + tablet zat besi dan tablet zat besi.

Kekurangan hepcidin adalah penyebab patogen dari kelebihan zat besi di sebagian besar bentuk hemochromatosis keturunan. Hasil hepcidin insufisiensi dari mutasi yang merusak pada gen yang mengkode regulator hepcidin (HFE, TfR2 dan HJV) atau hepcidin itu sendiri. zat besi adalah hyperabsorbed, mengakibatkan deposisi kelebihan zat besi dalam hati dan parenkim lainnya. Tingkat defisiensi hepcidin berkorelasi dengan keparahan kelebihan zat besi: akibatnya pada ibu hamil akan mengalami masalah gastrointestinal seperti mual dan konstipasi, Stres oksidatif, keguguran berhubungan dengan preeklampsia (P. W., Rahma, H., \& Lubis, 2019)

Penyebab hepcidin mengalami peningkatan termasuk tingkat tinggi sitokin inflamasi, penurunan clearance hepcidin, atau mutasi pada regulator negatif hepcidin. IL-6 dan sitokin lain menyebabkan kadar hepcidin tinggi dalam gangguan autoimun, infeksi dan beberapa jenis kanker. Pada penyakit ginjal kronis (CKD), terlepas dari kehadiran umum dari peradangan, penurunan clearance hepcidin di ginjal juga dapat berkontribusi terhadap perkembangan anemia pada CKD. Akhirnyamutasi pada protease TMPRSS6, penekan hepcidin, mengarah pada pengembangan anemia defisiensi besi (Berglund, S., \& Lo, B. 2011).

Aktivitas kerja hepcidin dipengaruhi oleh sintesisnya.Keadaan yang meningkatkan sintesis hepcidin dikenal sebagai faktor yang positif seperti inflamasi dan peningkatan cadangan zat besi dalam tubuh yang berkaitan dengan asupan zat besi dari makanan.Sedangkan faktor negatif artinya menekan sintesis hepcidin seperti hipoksia, anemia, peningkatan eritropoesis dan penurunan cadangan zat besi dalam tubuh(Sebastiani et al., 2016)

\section{Kesimpulan}

Pemberian tablet zat besi dan teh daun kelor terbukti signifikan pada peningkatan kadar hemoglobin ibu hamil pada kelompok intervensi dimana nilai $p=0,001 \quad(p<0,05)$. Namun tidak terdapat nilai yang signifikan pemberian tablet zat besi dan teh daun kelor pada kadar hepcidin pada kelompok intervensi dengan nilai $p=0.429$ ( $p>0.05$ ), sehingga konsumsi tablet zat besi dan 
teh daun kelor lebih baik pada peningkatan kadar

Hemoglobin disbanding pada kadar hepcidin.

\section{Daftar Pustaka}

Dinkes. (2019). Profil Kesehatan kabupaten Sidenreng Rappang.

Kemenkes. (2016). Peraturan Menteri Kesehatan RI No.43 Tahun 2016 tentang Standar Pelayanan Minimal Bidang Kesehatan. 79.

Kemenkes RI. (2014). PMK No.97 Tahun 2014 Tentang Pelayanan Kesehatan. Artikel, [cited 2018 Jan 7]; 3-8. https://id.search.yahoo.com/search?p=PMK +No.97+th+2014+tentang+pelayanan+keseh atan+masa+sebelum+hamil\%2C+masa+ham il\%2C+persalinan+dan+sesudah+melahirkan \&fr=yfpt\&fp=1\&toggle=1\&cop=mss\&ei=UTF8\%0Akesga.kemkes.go.id

Kemetrian Kesehatan Republik Indonesia. (2018). Basic Health Research 2018. In Riskesdas 2018.

Nadimin, H. V, As'ad, S., \& Buchari, A. (2015). The extract of moringa leaf has an equivalent effect to iron folic acid in increasing hemoglobin levels of pregnant women: a randomized control study in the coastal area of Makassar. Int J Sci Basic Appl Res, 22(1), 287-294.

P. W., Rahma, H., \& Lubis, Z. (2019). Artikel Penelitian Korelasi Kadar Hepcidin Dan Kadar Feritin. 1-6.

Ratulangi, U. S., \& Kaligis, S. H. M. (2017). Gambaran Kadar Hemoglobin pada Mahasiswa dengan Indeks Massa Tubuh ( IMT) $\geq 23 \mathrm{~kg} / \mathrm{m} 2 \mathrm{di}$ Fakultas Kedokteran. 5.

Sebastiani, G., Wilkinson, N., \& Pantopoulos, K. (2016). Pharmacological targeting of the hepcidin/ferroportin axis. In Frontiers in Pharmacology. https://doi.org/10.3389/fphar.2016.00160

WHO. (2019). World Health Statistic Report. Geneva: World Health Organization.

Winarno. (2018). Tanaman Kelor (Moringa Oleifera) Nilai Gizi, Manfaat, dan Potensi Usaha. Gramedia Pustaka Utama.

Young, M. F., Oaks, B. M., Tandon, S., Martorell, R., Dewey, K. G., \& Wendt, A. S. (2019). Maternal hemoglobin concentrations across pregnancy and maternal and child health: a systematic review and meta-analysis. In Annals of the New York Academy of Sciences. https://doi.org/10.1111/nyas.14093 